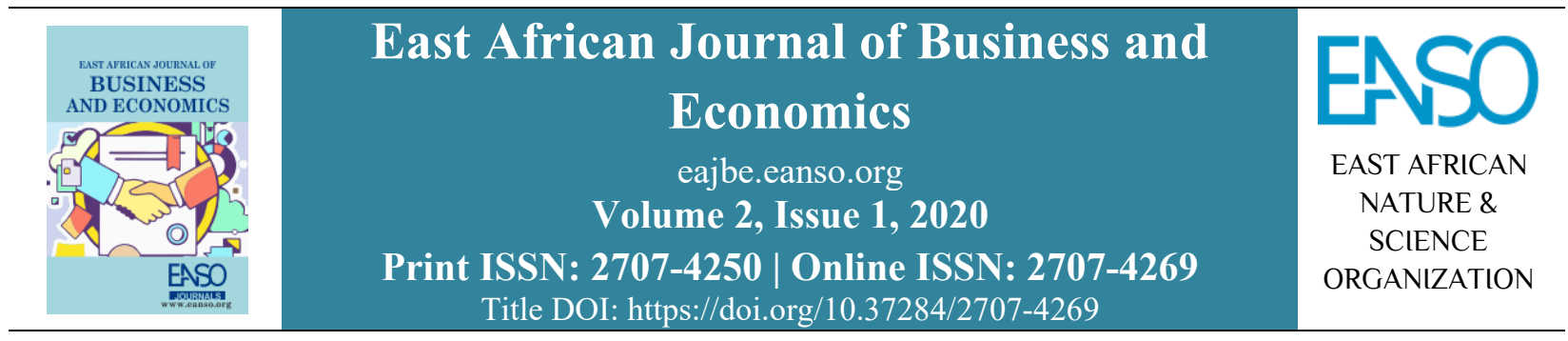

Original Article

\title{
Supply Chain Management Integration and Demand Management Practices on Organizational Performance of Kenya Medical Research Institute
}

\author{
Florence Chepkemoi Bongei ${ }^{1}$, Prof. Christopher Ngacho ${ }^{2}$, Dr. Yusuf Kibet ${ }^{3}$ \\ ${ }^{1}$ School of Business and Economics, Kisii University, P. O. Box 408 - 40200, Kisii, Kenya. \\ * ORCID: https://orcid.org/0000-0003-3559-4702; Correspondence email: fbongei@yahoo.com.
}

Article DOI: https://doi.org/10.37284/eajbe.2.1.248

\section{Date Published: ABSTRACT}

11 December 2020 Supply chain management has dual purposes; these are to improve the performance of an individual organization as well as that of the entire supply

Keywords: chain. An integrated supply chain links the customers, organization and suppliers, improves the lead-time, customer satisfaction and the flow of

Explanatory Research

Design,

Supply Chain

Management Practices,

Kenya Medical Research

Institute,

KEMRI,

Demand Management. information becomes rapid from consumers to sellers. This study examines the effects of Supply chain management integration practices on organizations' performance and establishes the effects of demand management practices on organizations performance. This study was guided by the supply chain operations reference model, and value chain model. The study used the explanatory research design to gather information. The study's targeted a population of 3518 employees from KEMRI from which a sample size of 359 respondents was selected. Self-administered questionnaires and both simple random and purposive sampling techniques were used. Data findings were interpreted and presented using frequency tables and charts as deemed appropriate. The findings of the study revealed that supply chain integration and demand management practices has a positive significant relationship with the overall organizational performance. The study therefore recommended that an investment was necessary in information systems, collective planning, organized workflow, supply chain innovation and continuous flow of information for enhanced organizational performance.

\section{APA CITATION}

Bongei, F. C., Ngacho, N., \& Kibet, Y. (2020). Supply Chain Management Integration and Demand Management Practices on Organizational Performance of Kenya Medical Research Institute. East African Journal of Business and Economics, 2(1), 7283. https://doi.org/10.37284/eajbe.2.1.241 


\section{CHICAGO CITATION}

Bongei, Florence Chepkemoi, Christopher Ngacho, and Yusuf Kibet. 2020. "Supply Chain Management Integration and Demand Management Practices on Organizational Performance of Kenya Medical Research Institute". East African Journal of Business and Economics 2 (1), 72-83. https://doi.org/10.37284/eajbe.2.1.248.

\section{HARVARD CITATION}

Bongei, F. C., Ngacho, C. and Kibet, Y. (2020) "Supply Chain Management Integration and Demand Management Practices on Organizational Performance of Kenya Medical Research Institute”, East African Journal of Business and Economics, 2(1), pp. 72-83. doi: 10.37284/eajbe.2.1.248.

\section{IEEE CITATION}

F. C. Bongei, C. Ngacho, and Y. Kibet, "Supply Chain Management Integration and Demand Management Practices on Organizational Performance of Kenya Medical Research Institute”, EAJBE, vol. 2, no. 1, pp. 72-83, Dec. 2020.

\section{MLA CITATION}

Bongei, Florence Chepkemoi, Christopher Ngacho, and Yusuf Kibet. "Supply Chain Management Integration and Demand Management Practices on Organizational Performance of Kenya Medical Research Institute". East African Journal of Business and Economics, Vol. 2, no. 1, Dec. 2020, pp. 72-83, doi:10.37284/eajbe.2.1.248

\section{INTRODUCTION}

Organization's performance has remained to be one of the core objectives of any business. Managers struggle to increase performance in day-to-day basis where they try strategies and tactics to maintain high performances. The dilemma of maintaining high performance is a complex concept where solutions are found in many avenues. In manufacturing industries, most managers focus on maintaining an agile supply chain practices that would enable goods to move quickly on the answer to the demand of the market demand. Its main agenda is to reduce fluctuation or bullwhip effect on the market. Most the managers would focus on ensuring the smooth transition of goods with low cost through economies of scales. Chesaro (2016) claimed that the supply chain is a very important part of a firm that controls the performance of a product in the market. Most of the taste and preference, quality and quantity among other attributes are the main focus of customers.

Nowadays most organizations have invested more in supply chain since its practices are key to becoming a market leader. According to Mwilu (2013), it is crucial to improve supply chain management practice to ensure the smooth movement of goods from origin to the final consumer. She contended that supply chain management involves the flow of goods including raw materials, unfinished goods, as well as finished goods starting from the manufacturing to consumption.

Lambert and Cooper (2000) discussed that the supply chain business process is a crucial part of integrating and networking common systems, sharing information, enabling connected products and linking buyers and suppliers. An integrated supply chain enables the continuous flow of goods and service where customers access their goods on time at the right state and place. Lambert (2008) further expounded in another paper that the product change \& commercialization, business stream administration, demand completion, request administration style, viable managing of service as well as management of consumer relationships are part of the factors of supply chain management that affect firm productivity. According to Hilletofth (2011), business differentiation can be realized with efficient and effective SCM. It prompts the researcher to investigate more on supply chain management practice and organizations' performance.

Integrated supply chain operations are crucial throughout business processes because it ensures constants supply of not only products but also necessary information and service to the final consumer. Chandrasekaran (2010) elaborated that 
key commercial operations such as sourcing, logistics and warehousing are integrated with other functional activities such as value addition which are appreciated by consumers and other stakeholders. In order to achieve supply chain cooperative competitive advantage, interorganizational knowledge sharing among strategic members is crucial (Mulwa, 2015). To achieve this supply chain amalgamation is important towards achieving supply chain efficiency.

According to Mohamed (2015), demand management is one other aspect of lean supply chain practice, which is concerned with balancing supply chain competencies to internal and external stakeholders. These practices include; demand development, interactive demand, prompting, ordering and evaluating demand.

Performance of a business can be determined with its ability to accomplish financial-based goals as well as market-based goals. In any supply chain management, the short-term direct production cycle time, reduce inventories and intensify the output while the long-standing aims are intensifying profit and market share of the supply chain. Organization measures financial ability utilizing ratio like ROE, ROA, profitability and sales over time. Organizations supply chain should then be oriented in achieving organizational performance. Chesaro (2016) showcased performance metrics as operational areas of utilization measures, performance to schedule, lead-time measures, preventive measures, quality and inventory productivity measures. The specific measures included; variances, period expenses, cost of quality safety, other scales are measured in currencies and quantity of production and profit contribution. Financial and marketing measuring criteria has been used to quantify performance which includes, use of overall competitive position, the development of market share, sales progress, ROI growth, return on investment (ROI), profit margin on sales as well as market share according to Cho et al., (2004).
KEMRI is a governmental parastatal that handles research-based issues in the health sector. The institute with a vast reach in Kenya has its headquarters in Nairobi with field stations in Kericho, Busia, Kisumu, Kilifi, Malindi and Kwale. In addition to the research laboratories, clinics and field site, the institute also has a graduate school and a production unit. The institute has also collaborated with international laboratories and projects. Overall, medical research is a costly demanding undertaking by nature. It requires high levels of collaboration, integration, highly skilled workforce, committed management, financial muscle and coordination in strategy execution (KEMRI strategic plan, 2013-2017).

Globalization has facilitated dynamic change in managing supply chain. This has riveted close consideration from business managers, experts as well as academicians. This is because major organizations have realized that supply chain management is crucial in obtaining manageable competition which is an advantage with considerable capability to enhance effectiveness as well as lower costs of state corporations. There is need to maintain a simple, effective and efficient supply chain while ensuring the quick and agile movement of goods and services through the chain. Since the supply chain is on the lead to substitute individual companies as the financial engine for generating value throughout the $21^{\text {st }}$ century, knowing the connection between practices of SCM and organizational productivity has become increasingly significant. For an effective and efficient quantifiable processes organizations, should be in a position to measure, control, manage and improve their practices involving customers, suppliers, and internal organizations' SCM. Highly performing companies have been able to integrate well the network between suppliers, customer and internal SCM of the organization. The aim of the study was to examine the effect of supply chain integration practices on organizations' performance as well as establish the effect of demand 
East African Journal of Business and Economics, Volume 2, Issue 1, 2020

Article DOI: https://doi.org/10.37284/eajbe.2.1.248

management practices on organizations'

performance.

\section{LITERATURE REVIEW}

\section{Theoretical Review}

Supply Chain Operations Reference (SCOR) Model framework used by management in enhancing communication and improve decision making within the organization, customers and suppliers (Supply Chain Council, 2007). This framework "provides a unique framework that links business processes, metrics, best practices and technology features into a unified structure to support communication among supply chain partners and to improve the effectiveness of supply chain management and related supply chain improvement activities" (SCC, 2009).

SCOR model provides improvement, measure, identify and reorganize supply chain process with organizational practices. The process enables the supply chain to be integrated with measurement, benchmarking and re-engineering (Naslund \& Williamson, 2010). This model would help the company analyse its supply chain across all levels of Supplier management, customer relations, demand management and integrating all these practices towards achieving supply chain efficiency which contributes towards the overall organizations' performance.

Value chain model as postulated and developed by Dr. Porter (1985 as cited in Bett, 2013). Any organization that deals with numerous activities that has an input and output in between are processing as system theory depicts. In health research industry activities can be primary or support activities. According to Porter cited by Bett (2013), the basic activities are inbound and outbound logistics, sales and marketing, operational value addition with secondary activities being infrastructure, technology adoption, human capital purchasing and supplies. 
According to Eric's investigation on consumer's value and multi-benefit of digital technology, Information Technology organizes, connects, integrates sources of information, saves time and reduces the cost of supplier and consumer in an organization (Lambert \& Cooper, 2000; Pohja, 2004 \& Almquist, 2018). Customers, suppliers and stakeholders' network in a firm is important for competitive advantage.

According to SCMR Report, South African (2015) found that there is poor public SCM data lacked uniformity. Oversight, accountability and transparency should be integrated with SCM data management system (SCMR Report, South Africa, 2015). Knowledge sharing, organizational learning and organizational innovativeness are important in examining the intra-organizational change in capabilities of the firm. Sharing information, organizational learning and innovativeness and taking risks is an important part of information, communication and technology of organization to create competitive advantage (Siro, 2014). The organizational creativity is important in the introduction to new technology. It has a positive impact on the acceptance of new technology.

\section{Demand Management Practices}

Lapide (2006) defined demand management as "making decisions and acting in real-time to track, assess, and handle real demand and supply in the context of plans and forecasts". It is a procedure that includes matching orders and stock amongst predicting/estimating rotations. Demand Management concentrates on a fast and satisfactory combination of producers desires so as to stabilize and deliberately align demand through effective skills within the supply chain. Inability to acquire accurate information is amidst some of the advanced demand orientated challenges in a supply chain, resulting to incompetent consumer service, deprived stock alternation, and high undesirable proportion heightened by the extensive variety of goods (Cecere \& Chase, 2012). Demand management uses predicting skills together with demand detecting, shaping, as well as conversion methods towards improving supply chain processes. The drive towards becoming market ambitious needs reconsidering demand holistically: the origin of demand indicators, and the combination of the demand indicator into horizontal processes.

Cecere and Chase (2012) clarified the concept of demand management as the formation of interactions between processes as well as marketing focused on understanding the marketplace as well as coming up with activities coordinated with the firm approach, creation capacity as well as end client's requirements. It integrates marketing and $\mathrm{SCM}$ as a process or a component of supply chain management. Demand management processes have become crucial as a share of the developing range of SCM. Currently integrated SCM is viewed as a powerful weapon in the arsenal of a firm which can increase benefits in a competitive market. It is no longer seen as an additional disengaged back-office function. Several forefront supply chain firms are assimilating essentials of it with consumer-facing abilities inside their order management procedures so as to fully form and produce consumer demand (Lapide, 2006). Mohamed (2015) concluded that firms had invested time and money in collaborative demand planning and communicating its demand forecasts to its supply chain partners. Memia (2018), efficient and operative implementation of continuous demand sourcing led to enhanced administrative routine. This was ascribed to surplus minimization, excellence management, forecasting and transport management.

\section{Summary of Research Gaps}

According to Memia (2018), on his paper on contemporary SCM practices in business organizations in Kenya, augmentation of supply chain practices is anchored on the level of technology adopted not only by the organization but also by the partner organization. In the most recent studies reviewed, focus has been industrial supply 
chains as opposed to organizational supply chains and how they cascade into the industry supply chain (Memia, 2018). Further, some scholars relied on secondary data to analyse the phenomenon under study.

The research will also note that most past studies have focused on service and manufacturing industries leaving a gap that this study wishes to fill (Memia, 2018). The study will base its findings on state research institutions in Kenya so as to corroborate its findings with those in the manufacturing and service sector and provide a different view on the effect of SCM practices on organizational performance.

\section{RESEARCH METHODOLOGY}

An explanatory research design was used for this study, with explanatory research, the main reason is to elaborate on why actions happen and shape, explain, spread, or examine concepts. The research was done at the Kenya Medical Research Institute's headquarter. KEMRI is well-known as a nationwide institution mandated to do research representing human health. The study targeted Research and development officers, technical team and administration staff from a population of 3518 employees at KEMRI headquarter. The sample size for this study was 359. The main information was obtained from the respondents, which included support staff, technical staff and research and development units within KEMRI being considered to understand better CSM practices at KEMRI. Other information was obtained using secondary data, where the information was helpful in making conclusions and recommendation in this study. A

Table 1: Supply Chain Integration questionnaire was the most appropriate data collection instrument that was utilized. Quantitative data was obtained using structured questionnaires and analysed through descriptive statistics. Descriptive statistics entailed mean and standard deviation. Inferential statistics was done where primary data were analyzed by use of multiple regression equation to evaluate the contribution of all variables on the dependent variable. Qualitative investigation was extracted from unstructured questions. This was used to obtain information using comparison with quantitative findings obtained.

\section{DATA ANALYSIS AND DISCUSSION OF FINDINGS}

\section{Effect of Supply Chain Integration on organizational performance.}

The study sought to determine the effect of supply chain integration practices on organizational performance of research institutions. Means and standard deviations were used to give the findings under this objective. The means were interpreted as follows, a mean score of 0-1 implied the majority of the respondents agreed to the statements to a very small extent, a mean value of 1.1-2.0 implied that majority of the respondents agreed with the statements to a small extent, a mean score of 2.13.0 implied that respondents neither agreed nor disagreed with the statements, a mean score of 3.14.0 implied that majority of the respondents agreed with the statements to a great extent and a mean score of 4.1-5 implied that the respondents agreed with the statements to a very great extent.

\begin{tabular}{llllll}
\hline & N & Minimum & Maximum & Mean & Std. Deviation \\
\hline supply chain innovation & 270 & 1.00 & 5.00 & 4.0613 & .69895 \\
operational efficiency & 270 & 1.00 & 5.00 & 4.1801 & .63408 \\
reduced production timelines & 270 & 1.00 & 5.00 & 4.1379 & .70991 \\
smooth flow of goods and services. & 270 & 1.00 & 5.00 & 4.2115 & .67887 \\
the continuous flow of information. & 270 & 1.00 & 5.00 & 4.1954 & .73126
\end{tabular}




\begin{tabular}{llllll} 
& N & Minimum & Maximum & Mean & Std. Deviation \\
\hline collective planning & 270 & 1.00 & 5.00 & 4.0579 & .62917 \\
workflow organization & 270 & 1.00 & 5.00 & 4.0579 & .68237 \\
innovative business models & 270 & 1.00 & 5.00 & 4.0698 & .69670 \\
robust Information system & 270 & 1.00 & 5.00 & 4.0734 & .65179 \\
\hline
\end{tabular}

Source: Field Data, (2020)

The findings indicate that the mean values obtained for the majority of the items were above 4.0 demonstrated excellent agreement with the statements to a great extent. The findings indicate that majority of the respondents agreed to a great extent with the statement; supply chain innovation $(M=4.0)$, collective planning $(M=4.0)$, workflow organization $(\mathrm{M}=4.0)$, innovative business models $(\mathrm{M}=4.0)$ and robust Information system $(M=4.0)$ and agreed to a very great extent to the statement; SCI achieved operational efficiency $(\mathrm{M}=4.1)$, SCI reduced production timelines $(\mathrm{M}=4.1)$, SCI enhanced smooth flow of goods and services $(\mathrm{M}=4.2)$ and SCI ensured continuous flow of information ( $\mathrm{M}=4.1)$. this was a clear indication that supply chain integration practices influenced organizational performance to a great extent. These findings were in line with Mulwa (2015) where they concluded that organizational performance was hugely impacted by the rate of use of technology especially supply chain information sharing and collaboration which led to reverse logistics and enhanced performance.

\section{Effects of Demand Management on organizational performance}

The study also sought to determine the effect of demand management on organizational performance of research institutions. Means and standard deviations were used to give the findings under this objective. The means were interpreted as follows, a mean score of 0-1 implied the majority of the respondents agreed to the statements to a very small extent, a mean value of 1.1-2.0 implied that most of the respondents agreed with the statements to a small degree, a mean score of 2.1-3.0 implied that respondents neither agreed nor disagreed with the statements, a mean score of 3.1-4.0 implied that most of the respondents agreed with the statements to a great degree and a mean score of 4.1-5 implied that the respondents approved the statements to a very great degree.

\section{Table 2: Demand Management}

\begin{tabular}{lrrrrr}
\hline & $\mathbf{N}$ & Minimum & Maximum & \multicolumn{2}{c}{ Mean Std. Deviation } \\
\hline $\begin{array}{l}\text { KEMRIs' SCM has in place adequate } \\
\text { demand forecasting technologies }\end{array}$ & 270 & 1.00 & 5.00 & 3.8516 & .67551 \\
$\begin{array}{l}\text { KEMRIs' SCM has in place real-time } \\
\text { demand sensing capabilities }\end{array}$ & 270 & 1.00 & 5.00 & 3.9333 & .59482 \\
$\begin{array}{l}\text { KEMRIs' SCM has a rigorous demand } \\
\text { shaping process }\end{array}$ & 270 & 1.00 & 5.00 & 3.6215 & .72950 \\
$\begin{array}{l}\text { KEMRIs' SCM demand translation is } \\
\text { responsive to customer needs }\end{array}$ & 270 & 1.00 & 5.00 & 3.7619 & .68482 \\
$\begin{array}{l}\text { KEMRIs' demand signals are integrated } \\
\text { across its partners }\end{array}$ & 270 & 1.00 & 5.00 & 3.7610 & .70896 \\
$\begin{array}{l}\text { There's reduced demand variability in } \\
\text { KEMRI's SCM }\end{array}$ & 270 & 1.00 & 5.00 & 3.7280 & .66918 \\
$\begin{array}{l}\text { KEMRIs' SCM demand management } \\
\text { has improved operational flexibility }\end{array}$ & 270 & 1.00 & 5.00 & 3.9531 & .65511
\end{tabular}




\begin{tabular}{lrrrrr}
\hline & $\mathbf{N}$ & Minimum & Maximum & \multicolumn{2}{c}{ Mean Std. Deviation } \\
\hline $\begin{array}{l}\text { KEMRIs' demand management has led } \\
\text { to waste minimization }\end{array}$ & 270 & 1.00 & 5.00 & 4.0430 & .68177 \\
$\begin{array}{l}\text { KEMRIs' demand management has led } \\
\text { to improved quality }\end{array}$ & 270 & 1.00 & 5.00 & 4.1362 & .69100 \\
\hline
\end{tabular}

Source: Field Data, (2020)

The findings show that the mean values obtained for the majority of the items were above 3.7 demonstrated that excellent agreement with the statements to a great extent. Demand forecasting technologies scored a mean of 3.8 indicating that demand forecasting technologies affected organizational performance to a great extent. Realtime demand sensing capabilities score a mean of 3.9 indicating that demand sensing capabilities influenced organizational performance to a great extent. Rigorous demand shaping scored a mean of 3.6 indicating that rigorous demand shaping influenced organizational performance to a great degree. Demand signals integration had a mean score of 3.7, reduced demand variability, waste minimization and improved operational efficiency both had a mean score of 3.7, 4.0 and 3.9 correspondingly indicating that they influenced on organizational performance to a great degree. Improved quality had a mean score of 4.1 indicating that it had influenced organizational performance to a very great extent.

Table 3: Performance Management

\section{Organizational Performance Management}

Further, the study sought to determine the effect of supply chain management practices on organizational performance of research institutions. Means and standard deviations were used to give the findings under this objective. The means were interpreted as follows, a mean score of $0-1$ implied the majority of the respondents approved the statements to a very small degree, a mean value of 1.1-2.0 implied that majority of the respondents approved with the statements to a small degree, a mean score of 2.1-3.0 implied that respondents neither agreed nor disagreed with the statements, a mean score of 3.1-4.0 implied that most of the respondents approved the statements to a great degree and a mean score of 4.1-5 implied that the respondents approved the statements to a very great degree.

\begin{tabular}{lrllll}
\hline & N & Minimum & Maximum & Mean & Std. Deviation \\
\hline Increased market share & 270 & 1.00 & 5.00 & 4.0923 & .71332 \\
Improved Quality service and products270 & 1.00 & 5.00 & 4.1769 & .68594 \\
Increased customer satisfaction & 270 & 1.00 & 5.00 & 4.0502 & .68863 \\
Increased sales volume & 270 & 1.00 & 5.00 & 4.0849 & .68802 \\
Reduced cost & 270 & 1.00 & 5.00 & 4.0654 & .66891 \\
Increased profits & 270 & 1.00 & 5.00 & 4.0739 & .67197 \\
Increased SC competitiveness & 270 & 1.00 & 5.00 & 4.1445 & .75056 \\
Reduced customer lead time & 270 & 1.00 & 5.00 & 4.1853 & .72898 \\
Reduced production cycle time & 270 & 1.00 & 5.00 & 4.2317 & .74214 \\
\hline
\end{tabular}

Source: Field Data, (2020)

The discoveries on table 4.11 above indicate that majority of the respondents demonstrated agreement with the statements on organizational performance to a great extent given the all the statements mean score was above 4.0 and a standard deviation of between 0.6 and 0.75 . Increased market 
share, increased customer satisfaction, Increased sales volume, Reduced cost and Increased profits scored a mean score of 4.0 indicating that most of the respondents approved the statements to a great degree. Improved Quality service and products, reduced customer lead time, reduced production cycle time, Increased SC competitiveness scored a mean of above 4.1 indicating that majority of the respondents agreed with the statement to a very great extent. The study discoveries were in line with the conclusions of Memia (2018) who operationalized organizational performance in terms of profit margin and sales growth, growth of marketable share, reduced cost and return on investment.

\section{Inferential Statistics}

\section{Supply chain integration practices had no significant influence on organizational performance}

To test the relationship between supply chain integration practices and organizational performance a simple regression equation was developed. The decision rule was that if the P-value was less than 0.05 , the null hypothesis was rejected and if the P-value was more than 0.05 the null hypothesis was accepted.

Table 4: Supply chain integration practices influence on organizational performance

\begin{tabular}{|c|c|c|c|c|c|}
\hline \multirow[b]{2}{*}{ Model } & \multicolumn{2}{|c|}{$\begin{array}{l}\text { Unstandardized } \\
\text { Coefficients }\end{array}$} & \multicolumn{2}{|c|}{$\begin{array}{l}\text { Standardized } \\
\text { Coefficients }\end{array}$} & \multirow[b]{2}{*}{ Sig. } \\
\hline & $\mathrm{B}$ & Std. Error & Beta & $\mathbf{t}$ & \\
\hline $1 \quad$ (Constant) & 2.736 & .270 & & 10.122 & .000 \\
\hline Supply Chain integration practices & .320 & .064 & .300 & 5.010 & .000 \\
\hline
\end{tabular}

Source: Field Data, (2020)

From the findings on table 4.17 above the P-value was 0.000 which implied that there was a positive significant influence of supply chain integration practices on organizational performance. The study, therefore, rejected the null hypothesis and affirmed the alternate that there was a significant positive influence of supply chain integration practises on organizational performance.

\section{Demand management practices had no significant influence on organizational performance}

To test for the relationship between demand management practices and organizational performance, a simple regression equation was developed. The decision rule was if the P-value was less than 0.05 , the null hypothesis was rejected and if the P-value was more than 0.05 then the null hypothesis was accepted.

Table 5: Demand management practices influence on organizational performance

\begin{tabular}{|c|c|c|c|c|c|}
\hline \multirow[b]{2}{*}{ Model } & \multicolumn{5}{|c|}{$\begin{aligned} \text { Standardized } \\
\text { Unstandardized CoefficientsCoefficients }\end{aligned}$} \\
\hline & B & Std. Error & Beta & $\mathbf{t}$ & Sig. \\
\hline 1 (Constant) & 3.266 & .230 & & 14.189 & .000 \\
\hline Demand Management Practices & .218 & .060 & .227 & 3.638 & .000 \\
\hline
\end{tabular}

Source: Field Data, (2020)

From the findings as indicated in table 4.18 above, the P-value was 0.000 . This implied that there was a positive significant influence of demand management practices on organizational 
performance. The study, therefore, rejected the null hypothesis and affirmed the alternate that there was a positive significant influence of demand management practices on organizational performance.

\section{CONCLUSIONS AND RECOMMENDATIONS}

\section{Summary}

The findings of the study indicate that there was a positive relationship between supply chain integration practices and organizational performance of research institutions in Kenya. The study then rejected the null hypothesis and confirmed the alternate that there was a significant positive relationship between supply chain integration and organizational performance of research institutions in Kenya.

The study findings indicate that demand management practices influenced organizational performance. The study found a positive significant relationship between demand management practices and organizational performance in research institutions in Kenya. The study, therefore, held that demand management practices were important indicators of organizational performance of research institutions in Kenya.

\section{Conclusions}

The study found a significant influence of supply chain integration on organizational performance. This significant influence could be attributed to waste minimization, supply chain innovation, information management systems, collective planning, workflow organization and continuous flow of information. The study concluded that effective supply chain integration led to improved organizational performance in terms of reduced customer lead time and increased competitiveness. Further, the study concluded that adoption of technology was equally important in streamlining integration in order to ensure effective supply chain integration.

The found that demand management had a strong influence on organizational performance. Among the areas that were found to have a strong influence on performance included; demand forecasting, demand sensing and interpretation, demand visibility and demand variability. Demand management was found to improved operational flexibility, waste minimization and improved quality in operation therefore improving on the organizational performance. Therefore, the study concluded that demand management as a supply chain practice was viewed to have huge potential in overcoming organizational performance challenges.

\section{Recommendation}

Similarly, the study recommends that supply chain integration was critical in enhancing performance. Investment was necessary in information systems, collective planning, organized workflows, supply chain innovation and continuous flow of information for enhanced organizational performance. Further, the study recommends the adoption of technology as a measure to enhance supply chain integration efficiency.

With regards to demand management, the study recommends that implementation of demand management practices of; demand sensing and interpretation, demand forecasting, demand visibility and demand variability sensing as measures to overcome organizational performance challenges was critical and organization needed to invest in them. 


\section{REFERENCES}

Almquist, E. (2018). How digital natives are changing B2B purchasing. Harvard Business Review. Disponivel em: https://hbr.org/2018/03/how-digital-nativesare-changing-b2b-purchasing.

Bett, S. (2013). Strategy Alignment with Value Chain For Sustainable Growth in Technology Related Industries. Internation Journal of Innovation Research and Development, 2(10), 158-162.

Bhuvaneswari, D. (2018). An Overview of Supply Chain http://www.fibre2fashion.com/industryarticle/5123/an-overview-of-supply-chainmanagement?page $=3$ retrieved on $21^{\text {st }}$ May 2018

Cecere, L. M., \& Chase, W. C. (2012). Bricks Matter: The Role of Supply Chains in Building Market-Driven Differentiation. SAS Institute Inc., Cary, North Carolina, USA.

Chandrasekaran, N. (2010). Supply Chain Management, Processes, System and Practices. Oxford University Press.

Chesaro, R. C. (2016). Supply chain management practices and operational performance of multinational manufacturing firms in Kenya (Doctoral dissertation, University of Nairobi).

Cho, D. W., Lee, Y. H., Ahn, S. H., \& Hwang, M. K. (2012). A framework for measuring the performance of service supply chain management. Computers \& Industrial Engineering, 62(3), 801-818.

Hilletofth, P. (2011). Demand-supply chain management: industrial survival recipe for new decade. Industrial Management \& Data Systems.

Lambert, D. M. (2008). An executive summary of Supply Chain Management: Process,
Partnerships, Performance, Jacksonville: The Hartley Press, Inc.

Lambert, D. M. (2008). Supply Chain Management: Processes, Partnerships, Performance (http://www.scm-institute.org), $3^{\text {rd }}$ edition.

Lambert, D. M. (2008). Supply Chain Management: Processes, Partnerships, Performance (http://www.scm-institute.org), $3^{\text {rd }}$ edition.

Lambert, D. M., \& Cooper, M. C. (2000). Issues in supply chain management. Industrial marketing management, 29(1), 65-83.

Lapide, L. (2006). Demand management revisited. Journal of Business Forecasting Methods and Systems, 25(3), 17.

Memia, F. K. (2018). Influence of Contemporary Supply Chain Practices on Performance of Large Manufacturing Firms in Kenya (Doctoral dissertation, JKUAT-COHRED).

Mohamed, A. F. (2015) Lean Supply Chain Management practices and organizational performance in public water sector in Kenya. (MBA thesis, University of Nairobi)

Mulwa, M. L. (2015, March 20). Determinants of supply chain practices in organizations, $1^{\text {st }}$ DBA-Africa Management Review International Conference.

Mwilu, J. M. (2013). Supply chain management practices and performance among public research institutions in Kenya (Doctoral dissertation, University of Nairobi).

Naslund, D., \& Williamson, S. (2010). What is management in supply chain management? - a critical review of definitions, frameworks and terminology. Journal of Management Policy and Practice, 11(4), 11-28.

Pohja, T. L. (2004, September). Some theoretical foundations of Supply Chain Management and 
Supply Networks: the role of social networks in selecting partners. In 20th IMP Group Conference-Copenhagen.

Russell, R. S., \& Taylor, B. W. (2011). Operations Management: Creating Value Among the Supply Chain. John Wiley and Sons Inc. $7^{\text {th }}$ Edition.

Siro, D. (2014). The effect of ICT application on communication efficiency in the ministry of education, science and technology (Doctoral dissertation, University of Nairobi).

South Africa Report (2015). Public Sector Supply Chain Management Review. South Africa. Republic of South Africa.

Supply Chain Council (2007). Supply Chain Strategy Report: Make the Most of Supply Chain Strategy. APICS Insight and Innovation.

Supply Chain Council (2009). Supply Chain Strategy Report: Make the Most of Supply Chain Strategy. APICS Insight and Innovation. 